\title{
Development and Validation of a Discriminative Dissolution Medium for a Poorly Soluble Nutraceutical Tetrahydrocurcumin
}

\section{Zayıf Çözünür Bir Nutrasötik Olan Tetrahidrokurkumin İçin Ayırt Edici Bir Dissolüsyon Ortamının Geliştirilmesi ve Yöntemin Doğrulanması}

\author{
(D) Habibur Rahman SHIEK ABDUL KADHAR MOHAMED EBRAHIM*, (D) Telny Thomas CHUNGATH², (D) Karthik SRIDHAR¹, (D) Karthik SIRAM¹, \\ (D) Manogaran ELUMALAI ${ }^{3}$, (D) Hariprasad RANGANATHAN1, (D) Sivaselvakumar MUTHUSAMY4 \\ 1PSG College of Pharmacy, Department of Pharmaceutics, Coimbatore, India \\ ${ }^{2}$ Chemists College of Pharmaceutical Sciences and Research, Department of Pharmaceutical Analysis, Ernakulum, India \\ 3UCSI University Faculty of Pharmaceutical Sciences, Department of Pharmacology, Kuala Lumpur, Malaysia \\ 4PSG Institute of Medical Sciences \& Research Centre for Molecular Medicine and Therapeutics, Department of Pharmaceutical Analysis, Coimbatore, India
}

\begin{abstract}
Objectives: The present study aimed to develop and validate a discriminative dissolution method for tetrahydrocurcumin (THC), a Biopharmaceutical Classification System class II drug, by a simple ultraviolet (UV) spectrophotometric analysis. The final dissolution medium composition was selected based on the solubility and stability criteria of the drug.

Materials and Methods: As a prerequisite for this, the solubility of the drug was assessed in media of different pH (1.2-7.4), and surfactant concentrations of $0.5-1.5 \%(\mathrm{w} / \mathrm{v})$ sodium lauryl sulfate $(\mathrm{SLS})$ in water, and $\mathrm{pH} 7.4$ phosphate buffer. The dissolved drug concentration in each medium was quantified by UV analysis at $280 \mathrm{~nm}$ wavelength.

Results: The drug solubility was found to be high at a pH of 1.2 and 7.4. The media with surfactant enhanced solubility of the drug by approximately 17 -fold and exhibited better sink conditions. The discriminative power of the developed dissolution medium (i.e., 1\% w/v SLS in pH 7.4) was determined by performing in vitro dissolution studies of the prepared THC tablets and comparing their release profiles using fit factors (f1 and f2). The results of the fit factor comparisons made between the dissolution profiles of THC tablets proved the discriminative ability of the medium. The validation of the developed dissolution method was performed by international guidelines and the method showed specificity, linearity, accuracy, and precision within the acceptable range.

Conclusion: The proposed dissolution method was found to be adequate for the routine quality control analysis of THC, as there is no specified dissolution method for the drug in the pharmacopoeia.
\end{abstract}

Key words: Tetrahydrocurcumin, sodium lauryl sulfate, solubility, dissolution medium, dissolution comparison, fit factors

ÖZ

Amaç: Bu çalışma, bir Biyofarmasötik Sınıflandırma Sistemi sınıf II ilacı olan tetrahidrokurkumin (THC) için basit bir ultraviyole (UV) spektrofotometrik analiz ile tayinini sağlayacak bir dissolüsyon yöntemi geliştirmeyi ve doğrulamayı amaçlamıştır. Nihai dissolüsyon ortamı bileşimi, ilacın çözünürlük ve stabilite kriterlerine göre seçildi.

Gereç ve Yöntemler: Bunun için bir ön koşul olarak, ilacın çözünürlüğü suda ve pH 7,4 fosfat tamponunda farklı pH (1,2-7,4) değerlerinde ve \%0,5-1,5 (a/h) sodyum lauril sülfat (SLS) yüzey aktif madde konsantrasyonlarında değerlendirildi. Her bir ortamdaki çözünmüş ilaç konsantrasyonu, $280 \mathrm{~nm}$ dalga boyunda UV analizi ile ölçülmüștür.

Bulgular: İlaç çözünürlügünün pH 1,2 ve 7,4'te yüksek olduğu bulundu. Yüzey aktif madde içeren ortam, ilacın çözünürlüğünü yaklaşık 17 kat artırdı ve daha iyi sink koşulları sergiledi. Geliștirilen çözünme ortamının ayırt edici gücü ( $\mathrm{pH}$ 7,4'te \%1 w/v SLS), hazırlanan THC tabletlerinin in vitro çözünme çalışmaları yapılarak ve uygunluk faktörleri (f1 ve f2) kullanılarak salım profillerinin karşılaștırılması yoluyla belirlendi. THC tabletlerin

*Correspondence: hablet1@gmail.com, Phone: 09894229078, ORCID-ID: orcid.org/0000-0003-2609-4677

Received: 29.07.2020, Accepted: 19.01.2021

๑Turk J Pharm Sci, Published by Galenos Publishing House. 
çözünme profilleri arasında yapılan uyum faktörü karşılaştırmalarının sonuçları, ortamın ayırt etme kabiliyetini kanıtlamıştır. Geliştirilen çözünme yönteminin validasyonu uluslararası kılavuzlar kullanılarak gerçekleştirildi ve yöntem kabul edilebilir aralık içinde özgüllük, doğrusallık, doğruluk ve kesinlik gösterdi.

Sonuç: Farmakopede ilaç için belirlenmiş bir dissolüsyon yöntemi olmadığından önerilen dissolüsyon yöntemi THC'nin rutin kalite kontrol analizi için yeterli bulunmuştur.

Anahtar kelimeler: Tetrahidrokurkumin, sodyum lauril sülfat, çözünürlük, çözünme ortamı, çözünme karșılaștırması, uyum faktörleri

\section{INTRODUCTION}

In recent years, significant attention has been paid to nutraceuticals, as they are advantageous over synthetic drugs having many pharmacological actions with little or no toxic effects. However, the bioavailability of nutraceuticals is often compromised due to their poor aqueous solubility. Many formulation methods have been proposed to enhance the solubility and bioavailability of these hydrophobic entities. Dissolution testing is an important quality control tool to identify the effects of manufacturing variability on product performance and to ensure batch to batch equivalence. ${ }^{2}$ In this context, there is an utmost need for a suitable and validated dissolution method for analyzing the nutraceutical formulations which endorses the development.

The choice of a medium for the dissolution studies of class II drugs of the Biopharmaceutical Classification System (BCS) is critical, and developing a suitable dissolution media has always been a challenge because of the hydrophobicity exhibited by the drugs of this class. More importance should be given to the solubility factor of a drug while designing a dissolution method. The medium used should be able to homogenously solubilize the drug for an accurate quantification of the released amount from the total drug dose of the dosage form at each time interval. On the other hand, the solubility of a drug is directly or indirectly dependent on many variables like the $\mathrm{pH}$ of the medium, temperature, $\log \mathrm{P}, \mathrm{pK}_{\mathrm{a}}$, and ionic behavior of the drug. ${ }^{3}$ Maintaining large aqueous sink conditions, alteration of $\mathrm{pH}$, and addition of co-solvents or surfactants are a few approaches that have been adopted in the development of a dissolution medium for poorly soluble drugs. ${ }^{4}$ Addition of surfactants is preferred widely as they enhance the solubility of hydrophobic drugs by reducing the surface tension of the medium, increasing the wetting of the drug, and by micellar solubilization [above critical micelle concentration (CMC)] in the media. Although bile salts in the gastro-intestinal (Gl) system acts as surfactants that help in solubilization of the drug in vivo, use of these bile salts externally for routine in vitro analysis is not possible as they are expensive. Hence, the use of surfactants in the dissolution medium may serve well as a reliable alternative to mimic Gl conditions. ${ }^{5}$ Among the different surfactants, anionic surfactants, like sodium lauryl sulfate (SLS), ${ }^{6-8}$ and non-ionic surfactants, like polysorbate- 80 , were commonly used by the researchers. 9.10

Moreover, the medium chosen to perform the in vitro dissolution studies of drug formulations should be discriminative enough to differentiate drug release patterns and help in identifying the formulation and process variables that affect the release of the drug from the dosage form during the initial stages of product development. ${ }^{11}$ For this purpose, the in vitro dissolution profiles of different batches of the formulation are often compared to understand the similarities or differences in the release pattern. Various statistical methods like analysis and calculated by a least square regression method and analysis of variance (ANOVA), model-dependent, and model independent approaches are being adopted to compare the dissolution profiles.12,13 Determination of fit factors, which include difference factor ( $f 1$ ) and similarity factor ( $f 2$ ), are one of the effective and feasible model independent methods of dissolution comparison. The Food and Drug Administration (FDA) also recommends the use of these fit factors for dissolution comparison in the guides for industry..$^{14-16}$

The natural herb curcumin [(1E,6E)-1,7-Bis(4-hydroxy-3methoxyphenyl)-1,6-heptadiene-3,5-dione] falls under the category of nutraceuticals, and tetrahydrocurcumin [(THC), 1,7-Bis(4-Hydroxy-3-Methoxyphenyl)Heptane-3,5-Dione] is one of the active metabolites of curcumin that exhibits similar pharmacological actions. ${ }^{17}$ THC showed potent antiinflammatory and antioxidant effects while compared to other curcuminoids. ${ }^{18}$ It inhibits the amyloid precursor protein based on QSAR studies and has the potential to be utilized to treat Alzheimer's disease. ${ }^{19}$ The bioavailability of THC is limited due to its poor solubility and absorption. The aqueous solubility of these drugs is low, and hence, it is classified into class II of BCS. ${ }^{20}$ The role of $\mathrm{pH}$ and surfactants in the dissolution of curcumin was previously studied by Rahman et al. ${ }^{21}$ In the present study, an attempt was made to develop a suitable dissolution medium for in vitro analysis of THC by employing a surfactant to enhance its solubility and to maintain the sink conditions. To the best of our knowledge, no previous study on the dissolution medium development for THC has been done. The solubility of THC in different $\mathrm{pH}$ media and in the presence of anionic surfactant SLS was studied, and the effect of different media on the solubility of the drug was assessed. The discriminative power of the developed dissolution medium was determined by comparing the dissolution profiles of the prepared THC tablets using fit factors ( $f 1$ and $f 2$ ).

\section{MATERIALS AND METHODS}

\section{Materials}

THC was a gift sample from Sami labs (Bangalore, India). SLS, disodium hydrogen phosphate, sodium dihydrogen phosphate, sodium acetate trihydrate, hydrochloric acid, and 
glacial acetic acid were purchased from Himedia (Mumbai, India). Microcrystalline cellulose [(MCC), Avicel PH 102, FMC biopolymer, USA] and polyvinyl pyrrolidone (Povidone K 30, BASF, Ludwigshafen, Germany) were purchased from Signet chemical corporation Pvt. Ltd. (Mumbai, India). Sodium starch glycolate (SSG), magnesium stearate, and talc were purchased from Amishi drugs and chemicals Pvt. Ltd. (Ahmedabad, India).

\section{Media preparation for dissolution studies}

The buffer solution of $\mathrm{pH} 1.2$ [0.1 N Hydrochloric acid $(\mathrm{HCl})]$ was prepared by dissolving $8.5 \mathrm{~mL}$ of concentrated $\mathrm{HCl}$ in $1000 \mathrm{~mL}$ of purified water. The acetate buffer of $\mathrm{pH} 4.0$ was prepared by transferring $362 \mathrm{~mL}$ of $0.2 \mathrm{M}$ glacial acetic acid $+148 \mathrm{~mL}$ of $0.2 \mathrm{M}$ sodium acetate solution into a volumetric flask, and the volume was made up to $1000 \mathrm{~mL}$ with purified water. For the preparation of phosphate buffers, $0.2-\mathrm{M}$ sodium dihydrogen phosphate $\left(\mathrm{NaH}_{2} \mathrm{PO}_{4}\right)$ and 0.2-M disodium hydrogen phosphate $\left(\mathrm{Na}_{2} \mathrm{HPO}_{4}\right)$ solutions were prepared initially. Then $255 \mathrm{~mL}$ of $0.2-\mathrm{M} \mathrm{NaH}_{2} \mathrm{PO}_{4}+245 \mathrm{~mL}$ of $0.2-\mathrm{M} \mathrm{Na}_{2} \mathrm{HPO}_{4}$ and $100 \mathrm{~mL}$ of $0.2-$ $\mathrm{M} \mathrm{NaH} \mathrm{PO}_{4}+400 \mathrm{~mL}$ of $0.2-\mathrm{M} \mathrm{Na}_{2} \mathrm{HPO}_{4}$ were mixed to obtain buffer solutions of $\mathrm{pH} 6.8$ and 7.4 , respectively. The $\mathrm{pH}$ of the solutions was adjusted with $\mathrm{NaOH}$ or acetic acid, and final, they volume was made up to $1000 \mathrm{~mL}$ with a purified water.

\section{Formulation of THC tablets by direct compression method}

$\mathrm{THC}$ tablets were prepared in our lab since no commercial THC tablets are available in the market yet. The tablets were prepared using MCC, Avicel PH 102 as filler, polyvinyl pyrrolidone (Povidone K-30) as a binder, and SSG as a disintegrating agent. Magnesium stearate and talc were used as an antiadhesive agent and glidant. Three different tablet batches: TF1, TF2, and TF3 with three different concentrations of binder $(5 \%, 7.5 \%$, and $10 \% \mathrm{w} / \mathrm{w}$ ) were formulated to determine the effect of binding strength on drug release and to evaluate the discriminative ability of the dissolution medium in identifying formulation changes among the three tablet batches. The amount of drug was equivalent to $100 \mathrm{mg}$ in every tablet, and the total tablet weight was $200 \mathrm{mg}$ (Table 1).

Before preparing the tableting mixtures, all the materials were sieved manually through a sieve with a mesh size of 0.595 $\mathrm{mm}$. The weighed quantities of the drug, filler, disintegrant, and binder were mixed in a polybag for $10 \mathrm{~min}$. Finally, magnesium stearate and talc were added to the initial mixture and blended for $3 \mathrm{~min}$. A total of 100 tablets from each batch with a $8.7-\mathrm{mm}$ diameter and 4.6- $\mathrm{mm}$ thickness were produced by the direct compression method using Rimek minipress II (Karnavati engineering Ltd., Ahmedabad, India). All tablets were compressed with a constant compression pressure of $12 \mathrm{kN}$.

\section{Determination of mechanical strength of the tablet}

The mechanical strength or crushing strength of the prepared tablets was determined by using the tablet testing apparatus (Model DHT-250, THERMONIK, Campbell electronics, Mumbai, India).

\section{Determination of critical micellar concentration}

The micelle formation is an intrinsic property of a surfactant which plays a major role in the solubilization of the drug. The two generally accepted models explaining the aggregation of surfactant monomers into micelles are the "mass-action model" and the "phase-separation model", and the concentration of surfactant at which the micelles are formed (CMC) is dependent on many factors. ${ }^{22,23}$ The CMC of SLS in water and $\mathrm{pH} 7.4$ phosphate buffers (PB) were determined by dye solubilization and drop number methods prior to the solubility studies of the drug in these media. In the former method, eosin $Y$ was added to various concentrations of SLS $(0.25-2 \% \mathrm{w} / \mathrm{v})$ prepared in water and $\mathrm{pH} 7.4 \mathrm{PBs}$, and shaken for $24 \mathrm{hr}$ at $37^{\circ} \mathrm{C}$. The residue was filtered, and the absorbance of the resultant solutions was measured at $542 \mathrm{~nm}$ ( $\lambda_{\max }$ of eosin Y) using a ultraviolet (UV)visible spectrophotometer (Shimadzu1650PC, Tokyo, Japan). The obtained absorbance values were plotted against the concentrations of a surfactant expressed in millimoles (0.009$0.069 \mathrm{mM} / \mathrm{mL}$ : $0.25-2 \% \mathrm{w} / \mathrm{v}){ }^{24}$ The surface tension of the surfactant solutions prepared in water and $\mathrm{pH} 7.4 \mathrm{PBs}$ were also determined by the drop number method using the following equation:

$$
\frac{\gamma_{l}}{\gamma_{w}}=\frac{n_{w}}{n_{l}} \times \frac{d_{l}}{d_{w}},
$$

where $\gamma_{l} \gamma_{l}$ and $\gamma_{W} \gamma_{W}$ are surface tensions of the liquid in test and water (71.97 dynes/cm), $n_{W} n_{W}$ and $n_{l} n_{l}$ are number of drop counts for water and liquid, and $d_{l} d_{l}$ and $d_{W} d_{W}$ are the densities of liquid and water.

Table 1. Composition of prepared tetrahydrocurcumin tablets showing weight in $\mathrm{mg}$ of excipients per tablet for a total average tablet weight of $200 \mathrm{mg}$

\begin{tabular}{|c|c|c|c|c|c|c|}
\hline & TF1 & & TF2 & & TF3 & \\
\hline Ingredients & Weight per tablet (mg) & $w / w \%$ & Weight per tablet (mg) & $w / w \%$ & Weight per tablet (mg) & $w / w \%$ \\
\hline THC & 100 & $50 \%$ & 100 & $50 \%$ & 100 & $50 \%$ \\
\hline Avicel PH 102 & 80 & $40 \%$ & 75 & $37.5 \%$ & 70 & $35 \%$ \\
\hline Sodium starch glycolate & 6 & $3 \%$ & 6 & $3 \%$ & 6 & $3 \%$ \\
\hline Povidone K-30 & 10 & $5 \%$ & 15 & $7.5 \%$ & 20 & $10 \%$ \\
\hline Magnesium stearate & 2 & $1 \%$ & 2 & $1 \%$ & 2 & $1 \%$ \\
\hline Talc & 2 & $1 \%$ & 2 & $1 \%$ & 2 & $1 \%$ \\
\hline
\end{tabular}

THC: Tetrahydrocurcumin 
A plot of surface tension vs. log concentrations of surfactant in millimoles ( -2.665 to $-1.158 \mathrm{mM} / \mathrm{mL}$ equivalent to $0.25-2 \% \mathrm{w} / \mathrm{v}$ ) was made to determine the point of micelle formation in both the media. ${ }^{25}$

\section{Solubility study of pure THC}

To assess the role of $\mathrm{pH}$ and surfactant in the solubility of $\mathrm{THC}$, the equilibrium solubility of the drug was determined in dissolution media of different $\mathrm{pH}(1.2-7.4)$ and $0.5-1.5 \%$ $(\mathrm{w} / \mathrm{v})$ SLS in water $(\mathrm{pH} 5.5)$ and $\mathrm{PB}(\mathrm{pH} 7.4)$. Excess of drug (approximately $50 \mathrm{mg}$ ) was poured into $20 \mathrm{~mL}$ of each of the media and were kept over the shaker at $37^{\circ} \mathrm{C}$ and shaken for 2 $\mathrm{hr}$. Then, $2 \mathrm{~mL}$ of samples were withdrawn at the end of $1 \mathrm{~h}$ and $2 \mathrm{~h}$, filtered $(0.45 \mu$ pore size cellulose esters membrane filter, Millipore Corp., Billerica, MA, USA) and diluted in methanol. The concentration of the dissolved drug in each medium was determined by measuring the absorbance and correlating it with the standard concentration curve of THC built using a UVvisible spectrophotometer (Shimadzu 1650PC, Tokyo, Japan) at a corresponding wavelength of $280 \mathrm{~nm}$ ( $\lambda_{\max }$ of THC). The solubility parameter was kept as one of the main criteria for selecting the composition of the dissolution medium.

\section{Dissolution method validation for the analysis of THC tablets}

The developed dissolution method was validated by evaluating specificity, accuracy, precision, linearity, filter suitability, and stability.

\section{Specificity}

Specificity testing was done to demonstrate the absence of interference of excipients or dissolution medium with the drug response at $280 \mathrm{~nm}$. For this purpose, the solutions of placebo (excipients without drug), placebo with drug, and reference standard was prepared and analyzed in a UV spectrophotometer (Shimadzu 1650PC, Tokyo, Japan).

\section{Accuracy and precision}

The accuracy of the method was determined by the recovery test of a known amount of THC added to the placebo. An initial stock solution was prepared in methanol, and the final concentrations of $4.8,6$, and $7.2 \mu \mathrm{g} \mathrm{mL}^{-1}$ in dissolution medium were obtained corresponding to $80 \%, 100 \%$, and $120 \%$ of the nominal assay concentration. The samples were analyzed in triplicate on different days. The same solutions were used to evaluate the precision of the method. Repeatability and interday precision were evaluated based on the relative standard deviation (RSD) of the results.

\section{Linearity}

Aliquot of a stock solution containing $100 \mu \mathrm{g} / \mathrm{mL}$ of THC was prepared in methanol. It was then transferred into $25 \mathrm{~mL}$ volumetric flask and diluted with dissolution medium to obtain final concentrations of 2, 4, 6, 8, and $10 \mu \mathrm{g} \mathrm{mL}-1$ and analyzed in a UV spectrophotometer (Shimadzu 1650PC, Tokyo, Japan). The solutions were analyzed in triplicate, and the linearity was evaluated by linear regression ANOVA.

\section{Filter suitability}

Generally, the filters used in the dissolution sample preparation must be evaluated to verify that it does not adsorb the drug and is adequate enough to filter the excipients which would otherwise interfere with drug analysis. The standard and sample drug solutions with a final concentration of $6 \mu \mathrm{g} \mathrm{mL}^{-1}$ prepared in the dissolution medium were used to carry out the test. The sample solutions were prepared using the placebo. Both the reference and sample solutions were subjected to filtration through a $0.45-\mu$ pore size cellulose esters membrane filter (Millipore Corp., Billerica, MA, USA), and recovery of the drug after passing through the filters was assessed. For a filter to be acceptable, the recovery must be within $98-102 \% .26,27$

\section{Standard and sample solution stability}

The stability of THC in the dissolution medium was evaluated to demonstrate that the drug solution created during the dissolution test is stable over the period of dissolution and analysis of the samples. For this purpose, both the standard and sample were subjected to dissolution in the developed dissolution medium at $37 \pm 0.5^{\circ} \mathrm{C}$ for $2 \mathrm{~h}$ to obtain a final concentration of $10 \mu \mathrm{g} \mathrm{mL}$ solution. The samples were assayed at $\mathrm{O} h$ at room temperature $\left(25 \pm 2^{\circ} \mathrm{C}\right)$, and after 24 and $48 \mathrm{hr}$ at both room and refrigerator temperature $\left(8 \pm 2^{\circ} \mathrm{C}\right)$. The assay was performed in triplicate and observed for any change in the absorbance values as indicates the degradation of the drug. The acceptable assay range to confirm the sample and standard stability is $98-102 \% .{ }^{28}$

\section{In vitro dissolution study of pure THC and tablet formulations}

The dissolution of pure THC and in vitro release studies of the prepared $\mathrm{THC}$ tablets in the developed dissolution medium were performed using USP II rotating paddle apparatus (Electrolab TDT-08L, Mumbai, India). The dissolution study of the pure drug was carried out by filling $100 \mathrm{mg}$ of pure THC into the hard gelatin capsules (capsule size two) and allowing it to sink in each of the dissolution media with the help of sinkers. The dissolution flask was filled with $900 \mathrm{~mL}$ of each dissolution medium, and the temperature was maintained at $37^{\circ} \mathrm{C}$. The speed of paddles was set at $50 \mathrm{rpm}$, and the distance between the paddle and bottom of the flask was $25 \mathrm{~mm}$. The same conditions were maintained to study the dissolution of prepared THC tablets in the developed dissolution medium. Six tablets of uniform weight were chosen from each batch (TF1, TF2, and TF3), and the study was carried out for $2 \mathrm{~h}$. The samples were collected at $5,10,15,30,45,60,90$, and $120 \mathrm{~min}$. A total of 5 $\mathrm{mL}$ sample was withdrawn at each time interval and replaced with a fresh dissolution medium to maintain the sink condition. The collected samples were filtered $(0.45-\mu$ pore size cellulose esters membrane filter, Millipore Corp., Billerica, MA, USA) and the amount of drug released, and the cumulative percentage of the drug released was determined by UV spectrophotometric analysis at $280 \mathrm{~nm}$. The method was repeated thrice $(n=3)$.

\section{Discriminating test on a developed dissolution medium}

The discriminative power of the developed dissolution medium was determined by comparing the dissolution profiles of the prepared THC tablets. Model independent approach of 
dissolution comparison was used to differentiate the in vitro release profiles of the tablets. The difference factor ( $f 1$ ) and similarity factor (f2) were determined using the following equations: ${ }^{29}$

Difference factor $(\mathrm{f} 1)=\frac{\sum_{t=1}^{n}\left(R_{t}-T_{t}\right)}{\sum R_{t}} \times 100$

Similarity factor $(f 2)=50 \log \left\{\left[1+\frac{1}{n} \sum_{t=1}^{n}\left(R_{t}-T_{t}\right)^{2}\right]^{-0.5} \times 100\right\}$,

where $\mathrm{n}$ is the number of time points, $R_{t}$ and $T_{t}$ are the dissolution values of the reference, and test formulations at time $t$.

No statistical method was used in this study.

\section{RESULTS}

\section{Determination of mechanical strength of the tablet}

The hardness of the tablets increased with the increase in binder concentration due to increased interparticular bonding. The tablets with lowest binder concentration ( $5 \% \mathrm{w} / \mathrm{w})$ exhibited an average crushing strength of $31.30 \mathrm{~N}$, whereas those of intermediate $(7.5 \% \mathrm{w} / \mathrm{w})$ and highest $(10 \% \mathrm{w} / \mathrm{w})$ concentrations exhibited $46.06 \mathrm{~N}$ and $61.74 \mathrm{~N}$, respectively.

\section{Determination of critical micellar concentration}

From the dye solubilization study, it was observed that the solubility of the dye gradually increased below CMC, and a sharp increase was observed at $0.017 \mathrm{mM}(0.5 \% \mathrm{w} / \mathrm{v})$ of SLS in water media, whereas the maximum solubility of the dye was at $0.035 \mathrm{mM}(1 \% \mathrm{w} / \mathrm{v})$ of SLS in $\mathrm{pH} 7.4$ buffer (Figure 1a). The concentration of the surfactant showing maximum solubility of the dye indicated CMC. Surfactants tend to reduce the surface tension of the solutions. The surface tensions of the aqueous and buffer solutions gradually decreased with increasing concentration of SLS below CMC. A sudden drop in surface tension was seen at $-1.76 \mathrm{mM}(0.5 \% \mathrm{w} / \mathrm{v})$ in aqueous solution. On the other hand, this drop in surface tension was observed at $-1.46 \mathrm{mM}(1 \% \mathrm{w} / \mathrm{v})$ of SLS in $\mathrm{PB}$ of $\mathrm{pH} 7.4$, indicating the CMC (Figure 1b).

\section{Solubility study of pure THC}

The solubility of the drug was high at an acidic $\mathrm{pH}$ of 1.2 $(113.4 \pm 3.41 \mu \mathrm{g} / \mathrm{mL})$ and a basic $\mathrm{pH}$ of $7.4(88.54 \pm 4.5 \mu \mathrm{g} / \mathrm{mL})$, and the drug exhibited less solubility at an intermediate $\mathrm{pH}$ of 6.8 which was only $66.7 \pm 5.05 \mu \mathrm{g} / \mathrm{mL}$ after $2 \mathrm{~h}$ of study (Figure $2 \mathrm{a}$ ). A previous stability study on curcumin and its metabolites in various $\mathrm{pH}$ conditions indicated that THC was more stable in basic $\mathrm{pH}$ conditions than acidic. ${ }^{30-32} \mathrm{On}$ the basis of the available stability information, further evaluation of drug dissolution in the presence of surfactants was carried out in a $\mathrm{PB}$ of $\mathrm{pH} 7.4$, though the solubility of drugs seems to be slightly higher in an acidic $\mathrm{pH}$ of 1.2 than a $\mathrm{pH} 7.4$. A substantial increase in the solubility of the drug was observed when tested in media with a surfactant. The dissolution of the drug increased with an increase in surfactant concentrations in both media (e.g., from 617.67 $\pm 6.55-808.33 \pm 5.31 \mu g \mathrm{~mL}^{-1}, 933.0 \pm 4.08-998.33 \pm 6.94 \mu \mathrm{g}$ $\mathrm{mL}^{-1}$, and $1746.33 \pm 5.31-1944.70 \pm 4.92 \mu \mathrm{g} \mathrm{mL}^{-1}$ in water; and from
$589.33 \pm 4.50-714.00 \pm 5.35 \mu \mathrm{g} \mathrm{mL}^{-1}, 1228.33 \pm 4.92-1271.67 \pm 5.73 \mu \mathrm{g}$ $\mathrm{mL}^{-1}$, and $1421.00 \pm 5.35-1572.33 \pm 5.79 \mu \mathrm{g} \mathrm{mL}^{-1}$ in $\mathrm{pH} 7.4 \mathrm{~PB}$ saline (PBS) (Figure $2 \mathrm{~b}$ ). The high initial solubility of $\mathrm{THC}$ at $0.5 \% \mathrm{w} / \mathrm{v}$ SLS in an aqueous surfactant medium relative to $\mathrm{pH} 7.4 \mathrm{~PB}$ was due to micelle formation and attainment of CMC at low levels of surfactant in water. However, CMC of SLS in pH 7.4 PB was attained only at $1 \% \mathrm{w} / \mathrm{v}$, which led to a high solubilization of the drug at this surfactant concentration in a PB than in water. The increase in solubility of the drug above $\mathrm{CMC}$ in both media is due to the increase in the micelle aggregation with an increase in the amounts of a surfactant. ${ }^{20}$ From the experimentally determined CMC and solubility data, it was observed that the CMC of SLS reached below 1.5\%. Thus, 1\% SLS in pH 7.4 PB was chosen as a suitable dissolution medium. The results are subjected to statistical analysis of ANOVA, and the standard error is incorporated in the solubility graph (Figure 2).

\section{Dissolution method validation}

\section{Specificity}

The specificity test demonstrated that there was no interference of the excipients and the dissolution medium in the quantitative determination of THC at $280 \mathrm{~nm}$. There was no change in the UV spectrum of the drug in the presence of excipients used for tablet preparation. This indicates that the developed UV
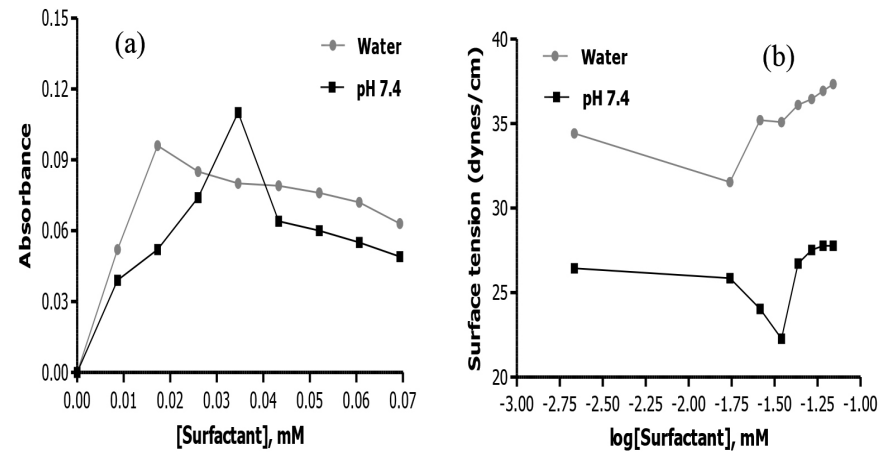

Figure 1. Experimental CMC values of SLS in water and $\mathrm{pH} 7.4$ phosphate buffer determined by (a) dye solubilization method and ( $b$ ) surface tension method.

CMC: Critical micelle concentration, SLS: Sodium lauryl sulfate
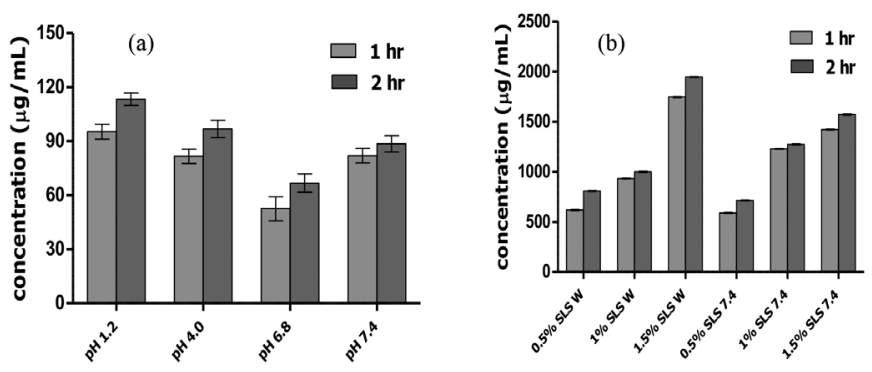

Figure 2. (a) Solubility profiles of pure tetrahydrocurcumin (THC) at $1 \mathrm{~h}$ and $2 \mathrm{~h}$ in different $\mathrm{pH}$ solutions of 1.2-7.4. (B) Solubility profiles of pure $\mathrm{THC}$ at $1 \mathrm{~h}$ and $2 \mathrm{~h}$ in water and $\mathrm{pH} 7.4$ containing $0.5-1.5 \% \mathrm{w} / \mathrm{v}$ sodium lauryl sulfate

( $p$ value less than 0.05 ) 
spectrophotometric method may be used for an assay of THC in dissolution studies.

\section{Accuracy and precision}

The accuracy of the method is evaluated by the recovery of the known amount of drug added to the placebo. The recommended recoveries in the dissolution tests should be in the range of 95-105\%. The mean recoveries of the drug for three different concentrations on different days were in the range 99.50$99.78 \%$, which demonstrated the accuracy of the method. The recovery results are presented in Table 2 . The inter-day and intra-day precisions were also evaluated for three different concentrations $\left(4.8,6.0,7.2 \mu \mathrm{g} \mathrm{mL}^{-1}\right)$ in two days. For a method to be precise, the RSD should be low (i.e., $\leq 2 \%$. From the results, the RSD was found to be $\langle 2 \%$, which demonstrated good precision of the method (Table 3 ).

\section{Linearity}

The linearity of the THC calibration curve for the concentration

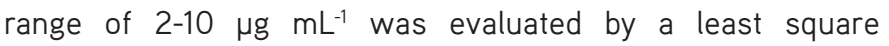
regression method and analyzed by ANOVA. The results showed good linearity, and the regression equation obtained was $y=0.031 x+0.028$. The correlation coefficient was found to be 0.9996 . Analysis by ANOVA showed significant linear regression $(p<0.05)$, and no significant deviation from the linearity.

\section{Filter suitability}

The average percentage recoveries of the standard and sample solutions after filtration were found to be within the range of 98-102\%. This showed the absence of any interference of the filter used in the analysis of the drug and that the filter used is suitable for the routine sample preparation in the dissolution test.

\section{Standard and sample solution stability}

The stability test of both standard and sample solutions showed that the drug is stable in the dissolution medium for a period of $48 \mathrm{~h}$ at both $25 \pm 2^{\circ} \mathrm{C}$ (room temperature) and $8 \pm 2^{\circ} \mathrm{C}$ (refrigerated conditions).This indicates that the drug did not form any degradation products in the dissolution medium (1\% $\mathrm{SLS}$ in $\mathrm{pH} 7.4 \mathrm{PBS}$ ). The results of the stability test are shown in Table 2.

\section{In vitro release study of pure THC and tablet formulations}

The dissolution of pure THC in different dissolution media was found to be solubility dependent. The cumulative percentage of the drug that released in $\mathrm{pH} 1.2,4.0,6.8$, and 7.4 was $40 \pm 1.8$, $30 \pm 4.7,23.8 \pm 2.67$, and $35.3 \pm 2.6$, respectively, at the end of 120 min (Figure 3a). The percentage of drug dissolved was found to be linearly dependent on the surfactant concentration, and a maximum drug release of $93 \pm 3.2 \%$ and $92 \pm 2.8 \%$ was seen in $1.5 \% \mathrm{w} / \mathrm{v}$ of SLS in water and $\mathrm{pH} 7.4$ PBS, respectively, at the end of $120 \mathrm{~min}$ (Figure $3 \mathrm{~b}$ ).

The release study of three tablet formulations TF1, TF2, and TF3 in 1\% w/v SLS in $\mathrm{pH} 7.4 \mathrm{~PB}$ showed varying drug release profiles. The prepared $\mathrm{THC}$ tablets differed in the amount of binder, the effect of which was reflected on their drug release pattern. Formulations TF1, TF2, and TF3 showed an initial drug release of $87.3 \pm 2.14 \%, 73.16 \pm 2.49 \%$, and $64.6 \pm 2.04 \%$, respectively in the first $5 \mathrm{~min}$ of the study (Figure $3 \mathrm{c}$ ). The overall release of a drug from tablet formulations was found to be retarded with an increase in the binder concentrations. As is evident from the hardness test, the crushing strength of the tablets increased as the amount of the binder increased. This caused a delay in the disintegration of the tablets, and hence, the formulations with higher binder concentrations showed a slow-release rate of the drug.

\section{Discriminating test on a developed dissolution medium}

The release profiles of formulations TF1, TF2, and TF3 were compared choosing four time points $(5,15,60$, and $120 \mathrm{~min}$ ) of the drug release curve, and the fit factors ( $f 1$ and $f 2$ ) were determined. Two release profiles were said to be similar when the value of difference factor ( $f 1$ ) is between 0 and 15 , and that of similarity factor ( $f 2$ ) is between 50 and 100.14,33 From the fit values, the release profile of formulation TF3 was found to be different from TF1 and TF2, and a slight similarity was observed between TF1 and TF2 (Table 3). Though similarity was observed between formulations TF1 and TF2 in terms of $\mathrm{f} 2$, which was at a border value of 51.61, a noticeable difference existed in the cumulative percentages of the drug released at initial time points of the study. This showed that the medium was able to differentiate the release rates of the prepared $\mathrm{THC}$ tablets.

Table 2. Stability data of tetrahydrocurcumin showing assay concentration of the drug in percentage at different storage temperatures and time periods

\begin{tabular}{|c|c|c|c|c|c|c|}
\hline & \multicolumn{2}{|c|}{$\begin{array}{l}\text { At } 0 \mathrm{~h} \\
\text { Initial: } 10 \mu \mathrm{gL}^{-1}\end{array}$} & \multicolumn{2}{|l|}{ At $24 \mathrm{~h}$} & \multicolumn{2}{|l|}{ At $48 \mathrm{~h}$} \\
\hline & Standard & Sample & Standard & Sample & Standard & Sample \\
\hline Refrigerator $\left(8 \pm 2^{\circ} \mathrm{C}\right)$ & $100.0 \%$ & $100.0 \%$ & $100.21 \%$ & $100.0 \%$ & $100.14 \%$ & $99.75 \%$ \\
\hline
\end{tabular}

Table 3. Fit factor values obtained from the drug release comparison of tetrahydrocurcumin tablets

\begin{tabular}{llll} 
Fit factors & TF1/TF2 & TF2/TF3 & TF1/TF3 \\
\hline f1 & 12.50 & 15.18 & 26.74 \\
\hline f2 & 51.61 & 41.29 & 33.52 \\
\hline
\end{tabular}



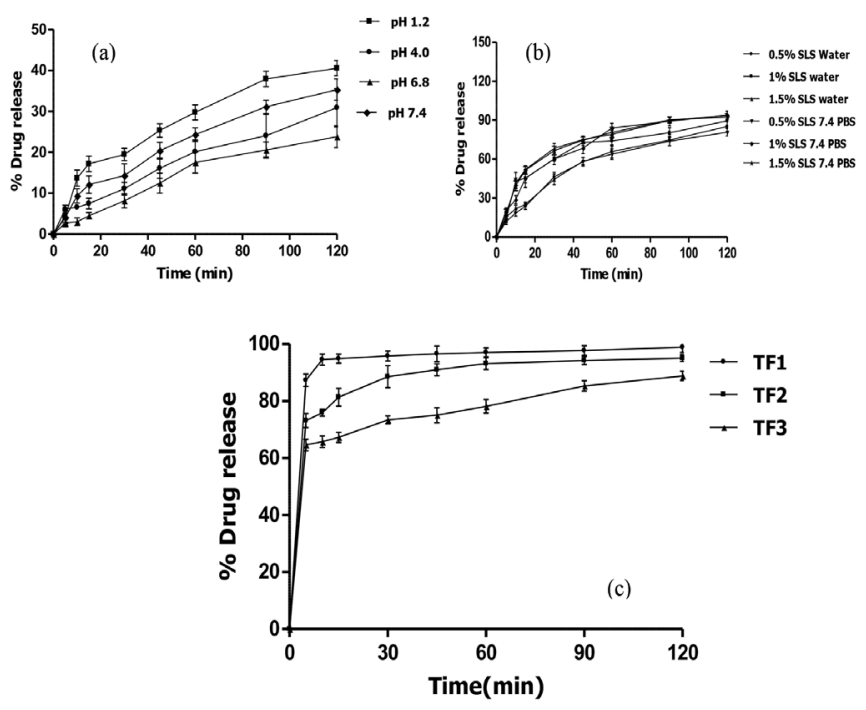

Figure 3. (a) Dissolution profiles of tetrahydrocurcumin (THC)-filled capsules in solutions of $\mathrm{pH}$ 1.2-7.4 ( $n=3)$. (b) Dissolution profiles of THC filled capsules in water and $\mathrm{pH} 7.4$ containing $0.5-1.5 \% \mathrm{w} / \mathrm{v}$ sodium lauryl sulfate $(n=3)$. (c) Cumulative percent drug release profiles of the prepared THC tablets in $900 \mathrm{~mL}$ of $1 \% \mathrm{w} / \mathrm{v}$ SLS in $\mathrm{pH} 7.4$ PBS at $50 \mathrm{rpm}(\mathrm{n}=3)$ PBS: Phosphate buffer saline

\section{DISCUSSION}

In the past decade, dissolution testing has undergone much transition in its application and value. Based on FDA guidance, dissolution test is applied as a surrogate marker for bioequivalence test along with quality control. ${ }^{34}$ On the other hand, there is very little published on the application of a dissolution in the development and testing of natural and nutraceutical products. Recently, there is lot of attention given for the nutraceutical product development because of its proven pharmacological actions. ${ }^{35-37}$ The present investigation was focused on the development of a discriminative dissolution medium, and its validation may serve as a reliable medium for quality assessment of THC formulations.

The initial CMC determination aimed to assess the contribution of surfactant in the solubility of the THC. The results of CMC determination by the drop number method was in agreement with those of the dye solubilization method. The critical concentration for micelle formation of the surfactant was low in aqueous solutions whereas it had increased in $\mathrm{pH} 7.4$. This is due to the presence of ions, which would have reduced the aggregation and formation of micelles at lower concentrations of SLS in $\mathrm{pH} 7.4$ buffers. $^{38}$

The increase in solubility of the drug in media with SLS was apparently due to the micellar solubilization of the drug by the surfactant. Surfactants are generally employed in developing the dissolution media of low soluble class II drugs to maintain sink conditions, and the required surfactant concentration depends on its CMC to solubilize $85 \%$ of the drug. The usual concentrations of SLS being used in the dissolution media are between 0.1 and $3 \% .39,40$ Apart from solubility of the drug, the suitability of a dissolution medium depends on the stability of the drug in the medium. Considering the stability of the drug, and on the basis of solubility data, 1\% SLS in a pH of 7.4 PBS was chosen as a suitable dissolution medium for THC.

Further in vitro release test of the prepared THC tablets was performed in $900 \mathrm{ml}$ of $1 \% \mathrm{w} / \mathrm{v}$ SLS in $\mathrm{pH} 7.4 \mathrm{~PB}$ with a paddle speed of $50 \mathrm{rpm}$, and the release profiles were compared. Generally, a paddle speed of 50/75 rpm was used to carry out the in vitro release studies of tablets by USP II paddle method. However, the dissolution medium may become indiscriminative when paddles are rotated at a higher agitation rate. ${ }^{41,42}$ Hence release studies were carried out at low agitation speed of 50 rpm to produce the steepest drug release profiles. The rate of release of the drug from each tablet formulation differed owing to the effect of the binder on a mechanical strength and disintegration of the tablets.

To elucidate the discriminative power of the medium, the dissolution curves of THC tablets were compared using the fit factors ( $f 1$ and $\mathrm{f} 2$ ). The release curves of $\mathrm{THC}$ tablets were compared at three different release time points before and one point after $85 \%$ of drug dissolution from all the tablets as per FDA guidelines. ${ }^{43}$ The difference or similarity observed between the release profiles of $\mathrm{THC}$ tablets was due to changes made in the formulation composition, and the developed dissolution medium was able to discriminate this. Further plasma absorption studies of THC formulations are required to establish reliable in vitro-in vivo correlation, and confirm the bio relevance of the medium.

\section{CONCLUSION}

Dissolution is crucial for low water-soluble compounds, because the absorption of these molecules is limited by their dissolution rate. In the case of THC, dissolution is an important rate-limiting step for absorption, so developing a suitable dissolution medium is necessary to predict differences in the bioavailability of the THC formulations. ${ }^{43}$ In the present study, the dissolution method for THC by UV spectroscopy was developed and validated. The results suggest that the $\mathrm{pH}$ of the medium and micellar aggregation of a surfactant in aqueous and ionic solutions influence the solubility of the drug. The final conditions for the dissolution test are $900 \mathrm{ml}$ of $1 \%$ SLS in $\mathrm{pH} 7.4$ PBS at $37 \pm 0.5^{\circ} \mathrm{C}$ as a dissolution medium using USP apparatus II with a paddle speed of $50 \mathrm{rpm}$. The validation showed that the developed dissolution method is appropriate for quantification of THC. The release profiles comparison of prepared THC tablets by a model independent approach and the determination of fit factors showed that $1 \%$ SLS in $\mathrm{pH} 7.4$ is a discriminative dissolution medium. Considering this, it may be concluded that the developed dissolution method is simple, cost effective, and adequate for the routine quality control analysis of THC, since there is no official monograph and validated method available. 


\section{ACKNOWLEDGMENTS}

The authors would like to thank Sami labs (Bangalore, India) for providing the gift sample of the drug.

Conflict of interest: No conflict of interest was declared by the authors. The authors are solely responsible for the content and writing of this paper.

\section{REFERENCES}

1. Kaya-Celiker $\mathrm{H}$, Mallikarjunan K. Better nutrients and therapeutics delivery in food through nanotechnology. Food Eng Rev. 2012;4:114-123.

2. Dressman JB, Amidon GL, Reppas C, Shah VP. Dissolution testing as a prognostic tool for oral drug absorption: immediate release dosage forms. Pharm Res. 1998;15:11-22.

3. Hörter D, Dressman JB. Influence of physicochemical properties on dissolution of drugs in the gastrointestinal tract. Adv Drug Deliv Rev. 2001;46:75-87.

4. Jinno J, Oh DM, Crison JR, Amidon GL. Dissolution of ionizable waterinsoluble drugs: The combined effect of $\mathrm{pH}$ and surfactant. J Pharm Sci. 2000;89:268-274.

5. Amidon GL, Lennernäs $H$, Shah VP, Crison JR. A theoretical basis for a biopharmaceutic drug classification: the correlation of in vitro drug product dissolution and in vivo bioavailability. Pharm Res. 1995;12:413420.

6. Bajerski L, Rossi RC, Dias CL, Bergold AM, Fröehlich PE. Development and validation of a discriminating in vitro dissolution method for a poorly soluble drug, olmesartan medoxomil: comparison between commercial tablets. AAPS PharmSciTech. 2010;11:637-644.

7. Jamzad S, Fassihi R. Role of surfactant and $\mathrm{pH}$ on dissolution properties of fenofibrate and glipizide-a technical note. AAPS PharmSciTech. 2006;7:E17-E22.

8. Lee H, Park SA, Sah H. Surfactant effects upon dissolution patterns of carbamazepine immediate release tablet. Arch Pharm Res. 2005;28:120126.

9. da Fonseca LB, Labastie M, de Sousa VP, Volpato NM. Development and validation of a discriminative dissolution test for nimesulide suspensions. AAPS PharmSciTech. 2009;10:1145-1152.

10. El-Massik MA, Darwish IA, Hassan EE, El-Khordagui LK. Development of a dissolution medium for glibenclamide. Int J Pharm. 1996;140:69-76.

11. Anand OM, Lawrence XY, Conner DP, Davit BM. Dissolution testing for generic drugs: an FDA perspective. AAPS J. 2011;13:328-335.

12. Yuksel N, Kanık AE, Baykara T. Comparison of in vitro dissolution profiles by ANOVA-based, model-dependent and-independent methods. Int $\mathrm{J}$ Pharm. 2000;209:57-67.

13. Costa P, Lobo JM. Modeling and comparison of dissolution profiles. Eur J Pharm Sci. 2001;13:123-133.

14. Guidance FD. Guidance for industry, immediate release solid oral dosage forms scale-up and postapproval changes: chemistry, manufacturing, and controls. Vitro dissolution testing, and in vivo bioequivalence documentation (SUPAC-IR). US Department of Health and Human Services, Food and Drug Administration, Center for Drug Evaluation and Research (CDER). 1995.

15. Guidance FDA. Guidance for industry: Dissolution testing of immediate release solid oral dosage forms. US Department of Health and Human
Services. Food and Drug Administration, Center for Drug Evaluation and Research (CDER). 1997.

16. SUPAC-MR FD. Modified release solid oral dosage forms: scale-up and post-approval changes: chemistry, Manufacturing, and Controls. Vitro dissolution testing and in vivo bioequivalenee documentation [S/OL]. (1997-09)[2009-08-18]. Available from: http://www. fda. gov/downloads/ Dmgs/GuidanceComplianceRegalatorvInformation/Guidances/ UCM070640, pdf. 1997.

17. Wu JC, Tsai ML, Lai CS, Wang YJ, Ho CT, Pan MH. Chemopreventative effects of tetrahydrocurcumin on human diseases. Food Funct. 2013;5:12-17.

18. Xiang L, Nakamura Y, Lim YM, Yamasaki Y, Kurokawa-Nose Y, Maruyama W, Osawa T, Matsuura A, Motoyama N, Tsuda L. Tetrahydrocurcumin extends life span and inhibits the oxidative stress response by regulating the FOXO forkhead transcription factor. Aging (Albany NY). 2011;3:10981099.

19. Kumar B, Garg V, Singh A, Pandey NK, Singh S, Panchal S, Melkani I Raji R, Axel M, Mohanta S, Jyoti J, Som S, Gulati M, Bhatia A, Prakash $\mathrm{T}$, Singh SK. Investigation and optimization of formulation parameters for self nanoemulsifying delivery system of two lipophilic and gastrointestinal labile drugs using box-behnken design. Asian J Pharm Clin Res. 2018;11:12-18.

20. Setthacheewakul S, Kedjinda W, Maneenuan D, Wiwattanapatapee R. Controlled release of oral tetrahydrocurcumin from a novel self-emulsifying floating drug delivery system (SEFDDS). AAPS PharmSciTech. 2011;12:152-164.

21. Rahman SM, Telny TC, Ravi TK, Kuppusamy S. Role of surfactant and pH in dissolution of curcumin. Indian J PharmSci. 2009;71:139-142.

22. Katritzky AR, Pacureanu LM, Slavov SH, Dobchev DA, Shah DO, Karelson M. QSPR study of the first and second critical micelle concentrations of cationic surfactants. Comput Chem Eng. 2009;33:321-332.

23. Drew M. Physical properties of surfactants used in cosmetics. In: Martin, M.R.; Linda, D.R. (eds.) Surfactants in cosmetics, New York: Marcel Dekker, INC; 1997:29-81.

24. Patist A, Bhagwat SS, Penfield KW, Aikens P, Shah DO. On the measurement of critical micelle concentrations of pure and technicalgrade nonionic surfactants. J Surfactants Deterg. 2000;3:53-58.

25. Mata J, Varade D, Bahadur P. Aggregation behavior of quaternary salt based cationic surfactants. Thermochim Acta. 2005;428:147-155.

26. Pharmacopoeial forum. Pharmacopoeial previews, 2004;30:351-363. Available from: https://www.uspnf.com/pharmacopeial-forum

27. Marques MR, Brown W. Desenvolvimento e validação de métodos de dissolução para formas farmacêuticas sólidas orais. Rev Analytica. 2002;1:48-51.

28. United States Pharmacopeial Convention. The United States Pharmacopeia 2011: USP 34; The national formulary: NF 29. Rockville, MD: United States Pharmacopeial Convention; 2010.

29. Shah VP, Tsong Y, Sathe P, Williams RL. Dissolution profile comparison using similarity factor, f2. Dissolution Technol. 1999;6:15.

30. Pan MH, Huang TM, Lin JK. Biotransformation of curcumin through reduction and glucuronidation in mice. Drug Metab Dispos. 1999;27:486494.

31. Hegde K, Shabaraya AR, Rao MN. Scavenging potential of reactive oxygen species by tetra-hydrocurcumin. J Appl Pharm Sci. 2011;1:114-118. 
32. Wang YJ, Pan MH, Cheng AL, Lin LI, Ho YS, Hsieh CY, Lin JK. Stability of curcumin in buffer solutions and characterization of its degradation products. J Pharm Biomed Anal. 1997;15:1867-1876.

33. Chow SC, Shao J. On the assessment of similarity for dissolution profiles of two drug products. J Biopharm Stat. 2002;12:311-321.

34. Dosage IS. Guidance for Industry Guidance for Industry Waiver of In Vivo Bioavailability and. Drugs, vol. FDA Guidan, no. August. 2000;16. Available from: https://www.fda.gov/files/drugs/published/Guidancefor-Industry-Bioavailability-and-Bioequivalence-Studies-for-OrallyAdministered-Drug-Products---General-Considerations.PDF

35. Dillard CJ, German JB. Phytochemicals: nutraceuticals and human health. J Sci Food Agric. 2000;80:1744-1756.

36. Lee J, Koo N, Min DB. Reactive oxygen species, aging, and antioxidative nutraceuticals. Compr Rev Food Sci Food Saf. 2004;3:21-33.

37. Mecocci P, Tinarelli C, Schulz RJ, Polidori MC. Nutraceuticals in cognitive impairment and Alzheimer's disease. Front Pharm. 2014;5:147.

38. Goddard ED, Harva O, Jones TG. The effect of univalent cations on the critical micelle concentration of sodium dodecyl sulphate. Transactions of the Faraday Society. 1953;49:980-984.
39. Noory C, Tran N, Ouderkirk L, Shah V. Steps for development of a dissolution test for sparingly water-soluble drug products. Am Pharm Rev. 2002;5:16-21.

40. Zhao F, Malayev V, Rao V, Hussain M. Effect of sodium lauryl sulfate in dissolution media on dissolution of hard gelatin capsule shells. Pharm Res. 2004:21:144-148.

41. Soni T, Nagda C, Gandhi T, Chotai NP. Development of discriminating method for dissolution of aceclofenac marketed formulations. Dissolution Technol. 2008;15:31.

42. Lagace M, Gravelle L, Di Maso M, McClintock S. Developing a discriminating dissolution procedure for a dual active pharmaceutical product with unique solubility characteristics. Dissolution Technol. 2004;11:13-18.

43. Guidance FD. Guidance for Industry: Dissolution Testing of Immediate Release Solid Oral Dosage Forms. US Department of Health and Human Services. Food and Drug Administration, Center for Drug Evaluation and Research (CDER). Rockville: U.S. Department of Health and Human Services Food and Drug Administration Center for Drug Evaluation and Research; 1997. 